\title{
Why is Corruption in the Healthcare Sector in Bulgaria so Common?
}

\author{
Jordan Deliversky, PhD*
}

\section{Summary}

The term corruption refers to everything from paying bribes to civil servants and large-scale theft from public funds to a wider range of economic and political practices that people consider abuses of power and that are increasingly criminalized.

Corruption thrives where transparency, accountability, and participation are weak, where the public sector and financial management capacities are low, and where public decision-making has been compromised by conflicts of interest and political interference. Corruption in the health sector can have severe consequences on the access to, quality, equity and effectiveness of health care services.

A key assessment tool for measuring vulnerability to corruption is a control system review or risk assessment. Control systems are the internal operational processes by which an organization makes decisions and uses resources to perform its mission. A control system review can help measure discretion, accountability, transparency and enforcement.

Keywords: Corruption, Healthcare, Bulgaria

The term corruption refers to everything from paying bribes to civil servants and large-scale theft from public funds to a wider range of economic and political practices that people consider abuses of power and that are increasingly criminalized(1).

There is no single, universally accepted definition of corruption. Usually the term is defined as "the abuse of public office for private gain" (Tanzi \& Davoodi 1997), with variants such as 'abuse of power' or 'abuse of entrusted authority'. Corruption is defined as deviation from the norm (Scott 1972) because it presumes

\footnotetext{
* Master of Insurance and Social Security; Doctor of Philosophy (Ph.D.), Organization and Management Outside the Sphere of Material Production, Media and Information Sciences; Department of National Security, State University of Library Studies and Information Technologies, Sofia, Bulgaria.
} 
that authority or office are entrusted to someone not to promote private gain of any kind (for self or others) but to promote the public interest, in fairness and impartiality.

The most commonly used definitions of corruption, refer to the abuse of public or entrusted power for private gain(2).

People generally cross the line between honest and corrupt behaviour when they have an opportunity to misuse their power and when they feel pressured to do so. Efforts to address the risks to corruption in the health sector usually contain a combination of legal, institutional and performance management measures.

The nature of corruption varies widely between countries. It is important to understand how corruption manifests generally in a specific country and then look into the specific sector. In order to address corruption in the health sector effectively, it is crucial to identify and understand the problem within the countrywide context and to design appropriate counter measures(3).

Specific emphasis should be given to awareness raising, prevention, detection and sanctions to bring about results. Corruption prevention and control also require authentic political commitment, sufficient knowledge of the health sector, and resources to implement strategies and interventions(4).

Corruption thrives where transparency, accountability, and participation are weak, where the public sector and financial management capacities are low, and where public decision-making has been compromised by conflicts of interest and political interference. Conversely, good governance can discourage corruption(5).

It is important for people working in the healthcare sector to have a shared understanding of what corruption is and to know how it is defined in the country's own constitution and laws. Many practitioners prefer a broad understanding of corruption that embraces anyone with entrusted power, including private sector staff, and any instance of corruption that occurs between private firms and within civil society organizations ${ }^{1}$.

The main types of corruption include the following:

$\checkmark$ Bribery: The offering, promising, giving, accepting or soliciting of an advantage as an inducement for action that is illegal, unethical or a breach of trust. Inducements can take the form of gifts, kickbacks, loans, fees, rewards or other valuables and advantages.

$\checkmark$ Collusion: A secret agreement between parties, in the public and/or private sector, to conspire to commit actions aimed to deceive or commit fraud with the objective of illicit financial gain.

$\checkmark$ Embezzlement: Act of dishonestly and illegally appropriating, using or trafficking the funds and goods office holders have been entrusted with for personal enrichment or other activities.

\footnotetext{
${ }^{1}$ Those in the private sector who willingly collaborate with corrupt government officials are equally guilty of corrupt practices when they offer and/or pay bribes in order to obtain an advantage for their firm. The same goes for employees of civil society organizations who embezzle funds or resort to bribes to win certain public contracts.
} 
$\checkmark$ Extortion: Act of utilizing, directly or indirectly, one's access to a position of power to demand unmerited cooperation or compensation as a result of coercive threats.

$\checkmark$ Favouritism/nepotism: favourable treatment of friends and associates in the distribution of resources and positions, regardless of their objective qualifications and merit.

$\checkmark$ Fraud: Act of an office holder of intentionally deceiving someone in order to gain an unfair or illegal advantage (financial, political or otherwise).

The different types of corrupt practices can be identified by reviewing the processes in the health care delivery system and examining the potential risks and abuses that could occur within them.

While certain forms of grand corruption may be more universally considered criminal or unethical, the often blurred lines between gifts, socially accepted favours and bribes, and other historical and social factors make it hard to define other forms of corruption. For example, some countries tightly regulate physician conflict of interest in ownership of medical ancillary services, whereas other countries do not. Most common practices in corruption in healthcare appear to be related to informal patient payments (giving gifts in-kind and cash payments). Informal payments include all unofficial payments for goods and services that are supposed to be free-of-charge and funded from pooled revenue as well as all official payments for which providers do not receive a receipt. Almost $63 \%$ of Bulgarians agree that the giving and taking of bribes, and the abuse of positions of power for personal gain, are widespread among people working in the public health sector ${ }^{2}$. The average informal payments rate for a physician's visit in Bulgaria is 8.23 euro, which is way lower than other European countries. Informal payments are higher for hospital admissions, approximately 44 euro.

In Bulgaria there is a system of mandatory social health insurance (SHI), which allows for the possibility to take out (additional) voluntary health insurance. The SHI contributions, which finance the National Health Insurance Fund (NHIF), are shared between employer and employee. Unemployed or self-employed citizens have to pay the contributions entirely by themselves. Two other important sources of financing, next to the SHI contributions, are out-of-pocket payments and general taxation. The National Revenue Agency is in charge of pooling the funds for both the central budget and the NHIF.

The NHIF is an autonomous public institution that is independent from the government. The NHIF is the sole responsible organisation for the $\mathrm{SHI}$ and is the main purchaser of healthcare services in Bulgaria. It is governed by a Supervisory Board (that includes representatives of the government, employers and insured individuals) and by the Governor of the Fund (who is elected by the National Assembly). The National Assembly has to approve and pass the NHIF budget annually.

Every year, the amount and prices of services are negotiated between the NHIF and the professional associations of physicians and dentists in Bulgaria. ${ }^{3}$ At the end of these negotiations the parties involved

\footnotetext{
${ }^{2}$ Sources: Special Eurobarometer 374, table QC4 (fieldwork September 2011); own research (fieldwork February/March 2013).

${ }^{3}$ By law four professional medical organisations are established and membership to these associations is mandatory (source: HiT report - Bulgaria, 2012)
} 
sign a National Framework Contract (NFC). The Regional Health Insurance Funds (RHIF) body then contracts providers that meet the criteria in the NFC. Selective contracting is not possible - the RHIF have to sign contracts with all public and private healthcare providers in their territory that satisfy the criteria. Many health service centres are owned by the state, such as university hospitals, specialised hospitals at the national level and centres for emergency medical care and psychiatric hospitals. The RHIF carry out healthcare at the regional level and the municipalities own a significant part of the providers. A share of the hospitals and many of the dental care centres, pharmacies and specialised outpatient care centres are in the private sector.

Corruption in the health sector can have severe consequences on the access to, quality, equity and effectiveness of health care services. Expensive hospital construction, high tech equipment and the increasing arsenal of drugs needed for treatment, combined with a powerful market of vendors and pharmaceutical companies, present risks of bribery and conflict of interest in the health sector.

According to the Advanced policy paper for discussion in the European Parliament, published in 2013, European union countries have been ranked according to performance by indicators using those proved to have a strong impact on corruption. According to this ranking, Bulgaria has been positioned among the countries presenting the highest risk of corruption. Bulgaria scores lowest on audit capacity, as well as on judicial independence and media freedom.

A key assessment tool for measuring vulnerability to corruption is a control system review or risk assessment. Control systems are the internal operational processes by which an organization makes decisions and uses resources to perform its mission. A control system review can help measure discretion, accountability, transparency and enforcement.

\section{Bibliography}

1. European Commission, Study on Corruption in Healthcare Sector, 2013

2. Vian T., Review of corruption in the health sector: theory, methods and interventions, Oxford Journal, vol.23, issue 2, 2007, p. 83-94

3. European Research Centre for Anti-Corruption and State-Building (ERCAS) at the Hertie School of Governance, Advanced Policy Paper for Discussion in the European Parliament, The Good, the Bad and the Ugly: Controlling Corruption in the European Union, 2013

4. Holmberg S, Rothstein B: Dying of corruption. Health Econ Policy Law 2011, 6:529-47.

5. Vian T: Review of corruption in the health sector: theory, methods and interventions. Health Policy Plan 2008, 23:83-94.

\section{Corresponding author:}

Jordan Deliversky, PhD

Department of National Security, State University of Library Studies and Information Technologies, 119 Tsarigradsko Shose bvld., 1784 Sofia, Bulgaria

Mob.: +359888856073, e-mail: deliversky@yahoo.com 